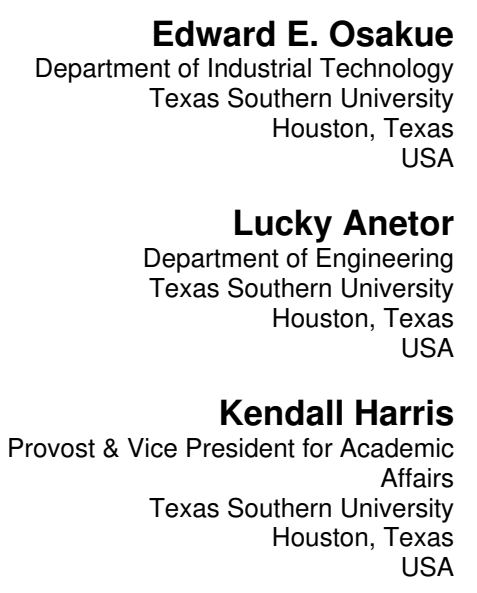

\section{Pitting Strength Estimate for Cast Iron and Copper Alloy Materials}

An attempt is made to predict the pitting strength of cast iron and copper alloy materials from their compressive yield or compressive proof strength for a reliability of $99 \%$ at $10^{7}$ load cycles. The compressive yield or compressive proof strength is related to the tensile strength of ductile cast iron and copper alloy materials by a proportionality factor. Two proportionality factors are used for brittle cast iron materials. The pitting strength formulation incorporates a nominal design factor at 99\% reliability which is estimated from a probabilistic model based on the lognormal probability density function. Pitting strength estimates from the predictions are compared with those of American Gear Manufacturers Association (AGMA) estimates and data from other sources. The predicted values for gray cast irons had variances in the range of $-11.28 \%$ to $25 \%$. Ductile cast iron pitting strength estimates deviated from those of AGMA by $-30.28 \%$ to $1.73 \%$ and $16.76 \%$ to $36.34 \%$ for Austempered ductile irons. The variances obtained for cast bronze were from $11.17 \%$ and $14.73 \%$, but the sample size was small. These variances appear to be reasonable due to the many factors that can influence pitting resistance. Since pitting strength data for many grades of cast iron and copper alloys are not available (especially in the public domain), they may be estimated by the expressions developed in this study for initial design sizing. Also, the pitting strength of new cast iron and copper alloy materials could likewise be estimated for initial design sizing. This will eliminate long and costly contact fatigue testing at the initial design phases, which of course is necessary for design validation.

Keywords: Hertz stresses, Pitting, Friction, Rolling-sliding, Fatigue, Reliability,

\section{INTRODUCTION}

Pitting strength is the contact stress capability of a surface loaded repeatedly in rolling or rolling-sliding motion. Below this stress capability, failure by pitting is prevented. The pitting damage occurrence is strongly influenced by the tribological system consisting of the contacting surfaces and the lubricant. The lubricant's base oil properties and additive substances, as well as the surface roughness are the main parameters commonly considered for an improvement of the pitting loadcarrying capacity of components. Nevertheless, the material strength plays a major role also in determining the pitting load-carrying capacity of components. There is common agreement that contact strength is influenced by Hertz stresses, load cycles, hardness, surface roughness, temperature, and degree of lubrication [1].

Contact fatigue which leads to pitting, results from repeated disturbance of the load pressing contacting surfaces together. Surface fatigue failure may be defined as the progressive loss of surface quality resulting from shearing and tearing away of particles from the active surface contact due to some combined rolling and sliding motions [2]. Contact fatigue process involves initiation of micro-cracks and crack propagation which can cause

Received: January 2021, Accepted: March 2021

Correspondence to Prof. Edward E. Osakue

Department of Industrial Technology

Texas Southern University, Houston, Texas, USA

Email: edward.osakue@tsu.edu

doi:10.5937/fme21022690

(C) Faculty of Mechanical Engineering, Belgrade. All rights reserved permanent damage to mechanical elements when the fracture toughness of the materials is exceeded [3, 4]. Only tensile stress leads to crack growth [5]. The repeated rolling or rolling-sliding contact conditions cause permanent damage to the material due to accumulation of plastic deformation [4]. In dry contact, surface failure may consist of a flaking of oxides. In lubricated surfaces, it may occur due to direct contact of asperities when the lubricating film thickness is not sufficiently developed for complete separation of the contacting surfaces. Shearing and tearing off of large particles may be from a portion of the contact surface. Rapid deterioration of contact surfaces may occur from insufficient lubrication, or from negligence in lubrication and protection from dirt [6]. Contact fatigue is extremely important for all engineering applications involving localized contacts such as in gears, brakes, clutches, ball bearings, rolling bearings, wheels and rails, cams and followers, chain hooks and chains, screws and riveted joints [7].

Contact fatigue related failures occur after more than 10,000 load cycles and there is no endurance limit in surface fatigue [8]. Surface treatments such as carburizing or nitriding give hard surface layers that can produce good fatigue and wear resistance [9]. American Gear Manufacturers Association (AGMA) gear pitting strength data are based on tests on actual gear teeth and is determined at $99 \%$ reliability and $10^{7}$ load cycles $[1,8]$ and at a temperature of $120^{\circ} \mathrm{C}$ and below [10]. The strengths are called nominal strength because they are modified for service or field applications using adjustment factors. 
Presently, the pitting strength of materials is determined experimentally. This is usually an expensive and time-consuming endeavor because it involves testing samples to failure [11]. The objective of this study is the prediction of the nominal pitting resistance capacity of cast iron and copper alloy materials. Osakue et al. [2] demonstrated that the pitting strength of steel materials can be related to their compressive yield strength or surface hardness. The compressive yield strength and tensile yield strength for most ductile materials are approximately the same, but are not for brittle materials. If the pitting strength of materials can be estimated from some more easily determined properties like yield strength or tensile strength, initial design may be done, and capacity performance testing can be carried out latter. This will eliminate initial experimentations for pitting strength determination, speed up product development, and reduce product cost.

\section{HERTZ CONTACT MODEL}

Hertz contact stress bears the name of the German physicist, Henry Hertz who first developed expressions for the stresses and deformations created when curved frictionless surfaces are statically loaded normally in 1881 [12]. Applications of Hertz theory are particularly useful in engineering for cylindrical and spherical contacts. Osakue et al. [2] showed that cylindrical contacts are more prone to pitting failure than spherical contacts. Therefore, only cylindrical contact is discussed in this study. Fig. 2a depicts the contact of two frictionless cylinders with the radii and the principal directions shown. The radius of each cylinder is in the $\mathrm{y}-\mathrm{z}$ principal plane. In the $\mathrm{x}-\mathrm{z}$ principal plane, the radius of each cylinder is infinite.

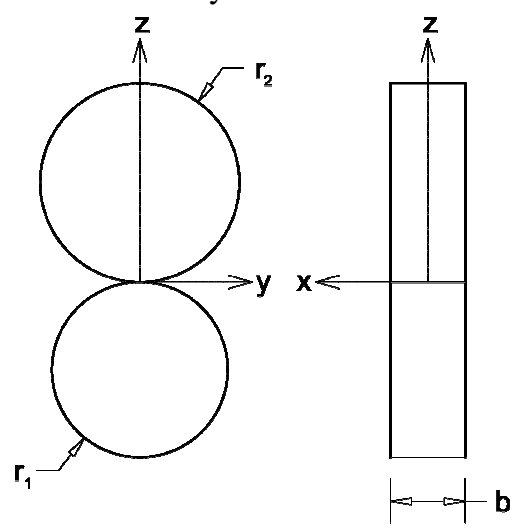

a) Two cylinders in contact

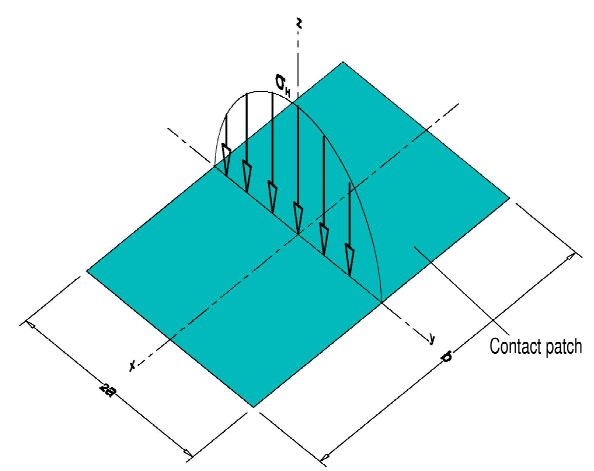

b) Contact pressure distribution

Fig. 2: Cylindrical contact
Fig. $2 b$ shows the stress distribution over the contact patch along the principal directions. The concentrated normal force acts along the $\mathrm{z}$-axis pressing the bodies together.

With reference to [2], the expression for the maximum contact pressure and the half-contact width may be rendered as in Eq. (1a) and eq. (1b), respectively.

$$
\sigma_{H}=-\left[\frac{K_{s} F_{c}}{\pi b_{e}} \frac{E_{c} \times 10^{3}}{\rho}\right]^{1 / 2} \quad a=\frac{2 K_{s} F_{c}}{\pi b_{e} \sigma_{H}}
$$

Equation (1) has two entries and should be interpreted as Eq. (1a) and Eq. (1b) from left to right. The same rule should be applied to other equations of similar nature.

Please refer to Nomenclature for the definition of variables and parameters.

In Eq. (1a):

$$
\begin{aligned}
& E_{c}=\frac{2 E_{1} E_{2}}{E_{1}\left(1-v_{2}^{2}\right)+E_{2}\left(1-v_{1}^{2}\right)} \\
& \rho=\frac{2 r_{1} r_{2}}{r_{2} \pm r_{1}} b_{e}=\lambda_{e} b
\end{aligned}
$$

In frictionless Hertzian contact under a static normal load, a localized complex stress state that is concentrated in a small volume of material is produced. A maximum shear stress is generated at some depth below the surface. Relative rolling motion between contacting bodies creates the same type of stress field as in static normal load but the contact patch and hence the stress field is in continuous motion. The stresses are therefore, subject to cyclic variation and the contacting surfaces are loaded in fatigue. The presence of relative sliding motion combined with rolling motion and or external tangential load, introduces tractions from frictional resistance between the contacting surfaces. The stress field is then modified and stress component values are higher than when tractive forces are not present in the contact zone. Specifically, the presence of sliding introduces a tensile stress component in the contact zone and leads to increases in contact stress component values as well as cause the location of the maximum shear stress below the contact surface to migrate upward $[2,13]$.

\section{THEORETICAL PITTING STRENGTH}

Pitting is the formation of tiny pits on surfaces of objects in rolling, or rolling-sliding motion in the presence of high contact stress. Pitting failure may originate from surface or subsurface cracks. Surface-originating pits are more prevalent than subsurface-generated cracks [14]. Surface cracks formation is facilitated by machining and grinding marks and surface flaws such as dents and scratches which when combined with geometric stress concentrations, greatly increases the possibility of surface cracks formation. Once a pit is formed, the site acts as a local stress concentration point which promotes formation of more cracks and pits.

The distortion energy (Von Mises) theory may be used to assess pitting failure when the materials in contact are ductile. Therefore, the equivalent contact stress at the surface is obtained as [15]: 


$$
\sigma_{e q}=\sqrt{\frac{1}{2}\left[\left(\sigma_{x}-\sigma_{y}\right)^{2}+\left(\sigma_{y}-\sigma_{z}\right)^{2}+\left(\sigma_{z}-\sigma_{x}\right)^{2}\right]}
$$

In frictionless cylindrical contact, the equivalent surface contact stress is given by Eq. (5) [2].

$$
\sigma_{e q}=\{\sqrt{1-2 v(1-v)}\} \sigma_{H}
$$

Objects in Hertzian contact are often associated with vibrational impact due to local acceleration and deceleration during meshing. Therefore, yielding of their surfaces should be related to the dynamic contact yield strength which tends to be higher than the static yield strength due to higher strain rate. For low-velocity impact or light-impact, the dynamic yield strength is approximately equal to the static yield strength and the dynamic contact yield strength of ductile materials may be obtained as given in Eq. $(6)[2,16]$.

$$
S_{y c}^{*}=(1.282+1.15 v) S_{y c}
$$

It may be assumed that pitting failure in a cylindrical contact occurs when the equivalent surface contact stress is at most equal to the dynamic contact yield strength as expressed in Eq. (7).

$$
\sigma_{e q}=\sqrt{1-2 v(1-v)} \sigma_{H} \leq S_{y c}^{*}
$$

From Eq. (7):

$$
\sigma_{H} \leq \frac{S_{y c}^{*}}{\sqrt{1-2 v(1-v)}}=S_{c}^{*}
$$

From Eq. (6) and Eq. (8):

$$
S_{c}^{*}=\frac{(1.282+1.15 v) S_{y c}}{\sqrt{1-2 v(1-v)}}
$$

Strain rate effect arising from impacts is ignored in Eq. (9) and applies to ductile materials. In contact problems, the state of stress is close to hydrostatic [2] which tends to increase the ductility of materials under tensile, compressive, and torsional tests. The increase has been observed not only with ductile metals but also with brittle metals and nonmetallic materials. Various brittle materials such as cast iron can deform plastically when subjected to hydrostatic pressure. The level of pressure to impact or enhanced ductility depends on the particular material [17]. Therefore, Eq. (9) should be applicable to brittle materials also, though in a more approximate sense.

The materials under consideration in this study are those of cast iron and copper alloys. Cast irons may be broadly classified into four types: gray cast iron (GCI), ductile cast iron (DCI), austempered ductile iron (ADI), and compacted graphite iron (CGI). The second letter in the acronyms stands for the type of cast iron. The most popular alloys of copper are brasses and bronzes. Brass is an alloy of copper and zinc with at least 50\% copper. Bronze is an alloy of copper and tin with composition ranges of 75 to $95 \%$ for copper and about 2 to $25 \%$ for tin. Common types of brass include red, free-cutting, cartridge and yellow brasses. Bronze types are described by the main alloying element such as aluminum, beryllium, manganese, phosphorus, lead, nickel, and silicon. Substituting Poisson's ratio values for the materials of interest from different sources [18, 19, 20] in Eq. (9) leads to Table 1.

Table 1: Theoretical Pitting Strength Prediction

\begin{tabular}{|c|c|c|}
\hline Material & $\begin{array}{c}\text { Poisson's } \\
\text { Ratio }\end{array}$ & $S_{c}^{*}(\mathrm{MPa})$ \\
\hline Gray cast iron & 0.260 & $2.0157 S_{y c}$ \\
\hline Austempered ductile iron & 0.250 & $1.9853 S_{y c}$ \\
\hline Compacted graphite iron & 0.260 & $2.0157 S_{y c}$ \\
\hline Ductile cast iron & 0.285 & $2.0914 S_{y c}$ \\
\hline Brass & 0.330 & $2.2246 S_{y c}$ \\
\hline Bronze & 0.340 & $2.2534 S_{y c}$ \\
\hline
\end{tabular}

\section{NOMINAL PITTING STRENGTH PREDICTION}

\subsection{Adjustment of Theoretical Pitting Strength}

The theoretical contact strength of Eq. (9) needs some modifications for practical applications. For instance, it does not account for the influence of friction which is important in real problems. Also, most strength data of materials such as yield strength, tensile strength and hardness are provided as minimum value which is unacceptable for use when failure is considered statistically [21]. Failure in contact is very close to a plane strain constrained phenomenon and should be considered too. From a reliability-based perspective, design parameters should have average or mean values and $50 \%$ reliability can be assumed for capacity models they are used in. However, higher reliability levels are usually required in practical situations. For example, AGMA gear pitting strength is assessed at $99 \%$ reliability and it is adopted as a reference in this study. Consequently, the nominal contact strength at $99 \%$ reliability for rolling-sliding motion may be expressed as:

$$
S_{c}^{\prime}=\frac{k_{s} k_{p} k_{o} S_{c}^{*}}{k_{c} n_{o}}
$$

Practically, the presence of friction due to relative sliding motion in the contact zone weakens the contact strength of the material, resulting in the lowering of the theoretical contact strength. This is taken into account by the contact strength sliding factor $k_{s}$. This parameter depends on the frictional properties and lubrication conditions of the contacting materials and is better determined from experiments. From [2], $k_{s}=0.80$ for bronze (phosphor) and $k_{s}=0.75$ for cast iron materials. Frictional property for brass is usually not as good as that of cast iron or bronze, so $k_{s}$ may be taken as 0.70 for it. Copious lubrication is assumed for the representative values stated.

The deformation of materials in Hertzian contact is constrained in at least one direction [22], very similar to plane strain deformation. The plane-strain yield strength is about 1.155 times the yield strength in uniaxial tension 
[17]. This parameter is actually the ratio of the failure stress prediction from maximum shear stress theory to distortion energy theory for biaxial stress state. Thus, a plane strain factor $k_{p}=1.155$ is appropriate in estimating pitting strength.

The design parameters used in the Hertz formula are average values that are associated with $50 \%$ reliability. However, higher reliability levels are usually required in practical situations; therefore, some probabilistic considerations cannot be avoided. AGMA specifies the nominal pitting strength of gear materials at a reliability of $99 \%$. This reliability level is used to evaluate the nominal designer factor in Appendix A3 for Eq. (10) and indicated in Table 2. The parameter $n_{o}$, is evaluated on the basis of the variability of design parameters and desired reliability level.

In probabilistic considerations, minimum and maximum values of design parameters are replaced with mean or average values [21]. However, most stress capability data available are given as minimum values. According to Hess et al. [23], the mean yield strength of ordinary structural steel is about 1.3 times the minimum. Therefore, $k_{0}=1.3$ is adopted in this study for all materials of interest. The parameter $k_{0}$, can be evaluated on the basis of the variability of material strength parameters and desired reliability level. If strength data available are in mean values, then the mean strength factor reduces to unity.

GCI normally contains cracks so it is not very notch sensitive [24]. The internal defects and inclusions in cast irons lead to low notch sensitivity [25]. In DCI, stress concentrations are reduced due to the presence of graphite nodules (spherical or elliptical in shape) embedded in cast iron matrix [26]. CGI has a complex coral-like graphite morphology that inhibits crack initiation and growth [19]. ADI has stabilized austenite that does not transform to brittle martensite and can undergo a strain-induced transformation when exposed to high normal forces. The transformation creates high compressive stresses in the "transformed" areas which inhibit crack formation and growth [27]. Generally, for materials permeated with internal discontinuities like cast irons, stress raisers usually have little effect, regardless of loading.

Generally, high ductility results in low notch sensitivity [28]. In the presence of ductile yielding, stress concentrations are relatively unimportant since the yielding occurs at the point of stress concentration, e.g. the tip of a notch, which merely redistributes the stresses and not necessarily lead to failure. If, however, there is only marginal ductility, or in the presence of low temperatures, then stress concentrations become more significant as the likelihood of brittle failure increases [29]. The ductility of copper alloys is in the range of 3 to $65 \%$ elongation [30]. They may be considered as having good to excellent ductility, except some that are severely strained- or aged-hardened. Some high strength alloys made by powder metallurgy can have a fracture strain of $2 \%$ and their un-notched components still exhibit yield at fracture; the fracture being of a tough ductile type [31]. Hence, it may be assumed that copper alloys are less sensitive to stress concentrations.

From the foregoing discussions, it is assumed that the surface contact stress concentration factor for cast iron and copper alloy products is unity; that is $k_{c}=1.00$ for this study. When local plastic deformation occurs near stress raisers, the stress concentration is reduced in magnitude and if a design accommodates plastic deformation, it may be reasonable to ignore stress concentration or incorporate it in a safety or design factor [31]. Table 2 is a summary of the foregoing discussions.

Table 2: Modification Factors for Theoretical Pitting Strength

\begin{tabular}{|c|c|c|}
\hline Parameter & Value & Remarks \\
\hline Mean strength factor & 1.300 & All materials \\
\hline Plain strain factor & 1.155 & All materials \\
\hline Surface stress conc. factor & 1.000 & All materials \\
\hline \multirow{3}{*}{ Strength sliding factor } & 0.700 & Brass \\
\cline { 2 - 3 } & $0.755+$ & Cast iron \\
\cline { 2 - 3 } & $0.800+$ & Bronze \\
\hline \multirow{2}{*}{ Nominal design factor } & $1.526 *$ & Wrought products \\
\cline { 2 - 3 } & $1.634 *$ & Cast products \\
\hline \multicolumn{2}{|c|}{ *From Appendix A3; + Ref. [2] } \\
\hline
\end{tabular}

\subsection{Nominal Pitting and Tensile Strengths}

As mentioned before, the materials under consideration in this study are those of cast iron and copper alloys. DCI and CGI are relatively ductile and tend to have approximately equal tensile and compressive strengths. ADI is relatively ductile and GCI is brittle but they have higher compressive strength than tensile strength. The most popular alloys of copper are brasses and bronzes. Copper alloys are generally ductile and can the heat treated, strained and age hardened. These treatments give them a wide range of mechanical strength properties. They tend to have approximately equal tensile and compressive strengths.

Materials may be described as linearly-symmetric or even, when the strength in compression is approximately the same as in tension. CGI, DCI and copper alloys will be considered as even materials. Materials may be described as linearly-asymmetric or un-even, if the strengths in compression are different from that in tension. ADI and GCI will be considered as un-even materials. Strength data available are most often that for ultimate tensile strength, not the yield strength, especially for brittle materials like GCI. Therefore, it is necessary to estimate the yield strength from the tensile strength as in Eq. (11).

$$
S_{y c}=\alpha_{y c} S_{u c}
$$

For linearly-symmetric materials, then:

$$
S_{u c}=S_{u t} \quad S_{y c}=\alpha_{y c} S_{u t}
$$

In the linearly-elastic region of the stress-strain diagram, the compressive elastic modulus and tensile elastic modulus for ductile or brittle materials are approximately the same. Therefore, the offset method used on tensile strength to obtain the tensile (proof) yield strength maintains the same slope on the compression side of the stress-strain curve as it is on the tension side, so that the proportionality factors $\alpha_{y c}$ and $\alpha_{y t}$ should have the same or approximately the same value. Therefore, Eq. (12b) may be rendered as:

$$
S_{y c}=\alpha_{y t} S_{u t}
$$


Table 3: Nominal Pitting Strength Expressions for Cast Iron and Copper Alloy Materials [1, 10, 20, 31]

\begin{tabular}{|l|c|c|c|c|c|c|c|c|}
\hline \multicolumn{1}{|c|}{ Material } & $S_{c}^{*}(\mathrm{MPa})$ & $k_{o}$ & $k_{s}$ & $k_{p}$ & $n_{o}$ & $\alpha_{y t}$ & $\alpha_{u c}$ & $S_{c}^{\prime}(\mathrm{MPa})$ \\
\hline Brass -wrought & $2.2246 S_{y c}$ & 1.30 & 0.700 & 1.155 & 1.526 & 1.000 & - & $1.533 S_{y t}$ \\
\hline Bronze-wrought & $2.2534 S_{y c}$ & 1.30 & 0.800 & 1.155 & 1.526 & 1.000 & - & $1.774 S_{y t}$ \\
\hline Brass-cast & $2.2246 S_{y c}$ & 1.30 & 0.700 & 1.155 & 1.634 & 0.400 & 1.000 & $1.774 S_{y t}$ \\
\hline Bronze-cast & $2.2534 S_{y c}$ & 1.30 & 0.800 & 1.155 & 1.634 & 0.500 & 1.000 & $0.828 S_{u t}$ \\
\hline Gray cast iron & $2.0157 S_{y c}$ & 1.30 & 0.755 & 1.155 & 1.634 & 0.563 & 3.386 & $2.666 S_{u t}$ \\
\hline Austempered ductile iron & $2.0157 S_{y c}$ & 1.30 & 0.755 & 1.155 & 1.634 & 0.722 & 1.490 & $1.482 S_{u t}$ \\
\hline Compacted graphite iron & $2.0157 S_{y c}$ & 1.30 & 0.755 & 1.155 & 1.634 & 0.700 & 1.000 & $0.979 S_{u t}$ \\
\hline Ductile cast iron & $2.0914 S_{y c}$ & 1.30 & 0.755 & 1.155 & 1.634 & 0.736 & 1.000 & $1.068 S_{u t}$ \\
\hline
\end{tabular}

Table 4: Nominal Pitting Strength Estimates for Some Cast Iron and Copper Alloy Materials [20, 31]

\begin{tabular}{|c|c|c|c|c|c|}
\hline \multirow{2}{*}{ Material } & \multirow{2}{*}{ Condition } & \multirow{2}{*}{$\begin{array}{l}\text { Tensile Strength } \\
\text { (MPa) }\end{array}$} & \multicolumn{2}{|c|}{ Nominal Strength, $S_{c}^{\prime}(\mathrm{MPa})$} & \multirow{2}{*}{$\begin{array}{c}\text { Deviation } \\
(\%)\end{array}$} \\
\hline & & & Published & Estimate & \\
\hline \multirow{3}{*}{ Gray cast iron } & Cast & 138 & $415[31]$ & 368 & -11.33 \\
\hline & Cast & 207 & $517[31]$ & 552 & 6.77 \\
\hline & Cast & 276 & $586[31]$ & 736 & 25.60 \\
\hline \multirow{4}{*}{ Ductile cast iron } & Annealed & 414 & $634[31]$ & 442 & -30.28 \\
\hline & Q\& $\mathrm{T}^{*}$ & 552 & $634[31]$ & 590 & -6.94 \\
\hline & Q\&T & 690 & $772[31]$ & 737 & -4.53 \\
\hline & Q\&T & 827 & $868[31]$ & 883 & 1.73 \\
\hline \multirow{5}{*}{ Austempered ductile iron } & \multirow{5}{*}{ Austempered } & 896 & $1138[20]^{+}$ & 1348 & 16.76 \\
\hline & & 1034 & $1241[20]^{+}$ & 1556 & 23.50 \\
\hline & & 1207 & $1345[20]^{+}$ & 1815 & 33.00 \\
\hline & & 1379 & $1517[20]^{+}$ & 2074 & 34.73 \\
\hline & & 1586 & $1724[20]^{+}$ & 2385 & 36.34 \\
\hline \multirow{2}{*}{ Bronze } & Sand cast & 276 & $206[31]$ & 229 & 11.17 \\
\hline & Heat treated & 620 & 448 [31] & 514 & 14.73 \\
\hline \multicolumn{3}{|c|}{ *Q\&T: Quenched \& Tempered } & & values & \\
\hline
\end{tabular}

For linearly-asymmetric materials, then:

$$
\begin{aligned}
& S_{y c}=\alpha_{y t} S_{u c} \quad S_{u c}=\alpha_{u c} S_{u t} \\
& S_{y c}=\alpha_{y t} \alpha_{u c} S_{u t}
\end{aligned}
$$

Eq. (13) indicates that the compressive yield or compressive proof strength can be related to the tensile strength of linearly-symmetric materials by a proportionality factor $\alpha_{y t}$. Similarly, Eq. (15) indicates that the compressive yield or compressive proof strength can be related to the tensile strength of linearly-asymmetric materials by two proportionality factors $\alpha_{y t}$ and $\alpha_{u c}$. The proof strength is the yield strength that is obtained by the strain offset method which is used for materials without apparent yield point. The parameters $\alpha_{y t}$ and $\alpha_{u c}$ are not usually provided in commonly available mechanical property datasets. Therefore, effort was made to research different sources of material property data that could be analyzed to generate representative values for the parameters. Estimates of $\alpha_{y t}$ and $\alpha_{u c}$ from limited data sets are provided in Appendix A2. Table 3 summarizes the results when values are substituted into Eq. (13), Eq. (15) and Eq. (10) combined with Tables 1 and 2 for the different material types under consideration. Please note that $k_{c}$ is omitted in Table 4 because of its unity value.

\section{ESTIMATES OF PITTING STRENGTHS}

Pitting strength data have been determined by AGMA [32] for most steel gear and some cast iron and copper alloy materials. Based on available data; comparisons with predictions from Table 3 are made in Table 4 . In the table, the tensile and pitting strength data in columns 3 and 4, respectively, were obtained from different sources $[1,10,20,31]$. The values for gray and ductile cast irons are expected maximum values. Column 5 in Table 4 contains pitting strength estimates based on expressions in Table 3. The deviations shown in column 6 of Table 4 are the percentage differences between published pitting strength and predicted data.

\section{DISCUSSIONS}

Eq. (9) gives the expression for the theoretical pitting strength of a material. It has two material property parameters of Poisson's ratio and the static compressive yield strength. The static compressive yield strength is used to approximate the dynamic contact strength of a material which could be influenced by strain rate during strong impact. Since light-impact is assumed in this formulation, strain rate influence is neglected. Eq. (9) is first of its kind in material and tribological technologies. Eq. (10) is the engineering approximation of the nominal pitting strength of a material. Most of the modification para- 
meters can be estimated from statistical variability data, except the strength sliding factor and the plane strain factor. The plain strain factor is evaluated theoretically and the strength sliding factor can be determined experimentally for a material pair. Some experimental data [2] and engineering judgments were involved in the values used in the current analysis.

A check on the last column of Table 3 shows that the nominal pitting strength of even-cast irons (CGI and DCI) is approximately equal to their tensile strengths. The nominal pitting strength of uneven-cast iron, ADI is about 1.5 times the tensile strength and that of GCI is about 2.7 times the tensile strengths. The nominal pitting strength of cast copper alloys is lower than their tensile strengths and the nominal pitting strength of wrought copper alloys is higher than their yield strengths.

The deviations in Table 4 show that the pitting strength estimates are lower than AGMA values for lowstrength $(<250 \mathrm{MPa})$ gray cast irons. Pitting strength estimate for high-strength $(\geq 250 \mathrm{MPa})$ gray cast iron is higher than published data value. This situation can be explained by the fact that the average compressive strength factor for gray cast iron is lower than actual values for low-strength materials, and higher than actual values for high-strength materials. Generally, deviations for ductile cast iron indicate that the pitting strength estimates are lower than AGMA values, suggesting that the expression in Table 3 is conservative. The average deviation for ductile cast iron is $-10 \%$. An attempt was made using the yield strength for pitting strength prediction for ductile cast iron, but the results were not as good as those shown for the tensile strength. The estimates for austempered ductile iron are higher than published values which are indicated as allowable values. This means the values have been derated for deign applications, so it is not too surprising to see the deviation values obtained for this material. The average deviation for austempered ductile iron is $28.87 \%$ (average is used because the values are all positive). The mechanical properties of CGI are midway of those of gray and ductile cast irons [24]. Therefore, good correlation is expected for this material, though no published data seem to be available now. The deviations for cast bronze materials are not unreasonable but the samples are too few for any definitive conclusion. Brass strength data are unavailable for comparison, but similar results as for bronze are anticipated. In all, it seems fair to say that the predicted pitting strength values in Table 4 are very good engineering estimates.

The pitting strength expressions are based on the compressive yield strength of a material, suggesting that the strength value should be for infinite load cycles. Since pitting is a wear type failure, the load cycles cannot be infinite. Now, AGMA values in Table 4 are for a load cycle of $10^{7}$ at a reliability of $99 \%$. Therefore, it is concluded that a load cycle of $10^{7}$ may be assumed for the expression developed.

No correction was made for surface stress concentration because cast irons are generally notch insensitive and copper alloys are usually quite ductile. However, allowance for stress concentration may be made through a design factor which can also accommodate other types of uncertainties. Generally, gear design procedures are not precise enough to account for the wide range of design situations [33]. Hence it is reasonable to allow for unknown factors in practice that could cause premature failure [1]. Consequently, in a design application, it is required that:

$$
n_{H}=\frac{S_{c}}{\sigma_{H}} \geq n_{c} \quad S_{c}=S_{c}^{/} Z_{c}
$$

Because most of the relevant factors are already accounted for in $n_{o}$, a modest value of $n_{c}$ should suffice. From Table 4, estimates for DCI and low-strength GCI are conservative, and those for copper alloys are less than $15 \%$ above AGMA values. Also, the estimate for highstrength GCI is about 25\% higher; and those for ADI are about $29 \%$ on the average above published values. Therefore, the following suggestions for $n_{c}$ are made:

$n_{c}=1.10 \quad$ DCI materials and low-strength GCI $n_{c}=1.15 \quad$ copper alloy materials

$n_{c}=1.30 \quad$ CGI, ADI and high-strength GCI materials Generally, in gearing applications, a value of 1.0 to 1.3 for $n_{c}$ is common. According to Petrov et al. [34], the minimum apparent design factor may be increased by $15 \%$ for critical gear drives.

The expressions for the pitting strength of wrought copper alloys in Table 3 should be applicable to different types and grades of brass and bronze which are in common use as gear materials and in other types of applications. Estimates from these expressions should be used with caution and good engineering judgment because no published data is used here to verify their accuracy. For example, an apparent design factor of at least 1.3 may be applied in preliminary design situation when estimates are made from the expressions. However, it should be noted that workhardening effects on pitting strength is usually neglected for cast irons but may be influential for copper alloys due to their high ductility. Workhardening tends to increase pitting resistance [2].

\section{CONCLUSIONS}

Expressions for pitting strengths based on the tensile strength of cast iron and copper alloy materials are derived and presented in Table 3 . The predicted strength values are for a reliability of $99 \%$ at $10^{7}$ load cycles. The expressions are based on the consideration of the Hertz stress formula for line contact and when the parameters therein are treated as random variables. The probabilistic solution is based on the lognormal probability density function and is quantified in a nominal design factor. Since common property data are specified as minimum strengths and mean strength values are required in probabilistic approaches [21], correction was made through a mean strength factor for data available as minimum values. If the data available are in mean values, then the mean strength factor reduces to unity. The formulation of the expression accounts for rolling-sliding motion through a contact strength sliding factor. Consideration is also taken of the fact that Hertz contact deformation is practically a plane strain deformation since the deformed volume is usually contained. Therefore, a plane strain deformation factor is used to account for this in the formulation. 
Pitting strength predictions from Table 3 are compared with those of AGMA estimates and data from [20] in Table 4. The pitting strength for low-strength gray and ductile cast irons are conservative and those for copper alloys are less than $15 \%$ above AGMA values. The estimate for high-strength GCI is about 25\% higher than AGMA value, but there are not many samples for comparison. The estimates for ADI are about $29 \%$ on the average above published values. These deviations are not unreasonable. The predicted pitting strength values appear sufficiently accurate for preliminary design applications.

\section{APPENDIX A: VARIABILITY AND DESIGN FACTOR}

\section{A1.0 CONTACT STRESS VARIABILITY}

The basic capacity model expression for cylindrical Hertzian contact is Eq. (1a) or Eq. (A1).

$$
\mu_{H}=-\left[\frac{K_{s} F_{c}}{\pi b_{e}} \frac{E_{c} \times 10^{3}}{\rho}\right]^{1 / 2}
$$

Assuming first order Taylor series expansion, the variability expression of Eq. (A1) is [2]:

$$
\vartheta_{m H}=\sqrt{\vartheta_{k a}^{2}+\vartheta_{k i}^{2}+\vartheta_{E c}^{2}+\vartheta_{b}^{2}+\vartheta_{\rho}^{2}+\vartheta_{m c}^{2}}
$$

It may be assumed that $\vartheta_{k a}=0.20$ and $\vartheta_{k i}=0.10$ in this analysis [2]. The cov of Young's modulus $\vartheta_{k i}=$ $0.04, \vartheta_{\rho}=0.001, \vartheta_{b}=0.01$, and $\vartheta_{m c}=0.05$ [2]. When values are substituted in Eq. (A8), then:

$$
\vartheta_{m H}=\sqrt{0.20^{2}+0.1^{2}+0.04^{2}+0.01^{2}+0.001^{2}+0.05^{2}}=0.229
$$

The general miscellaneous variability is obtained as:

$$
\vartheta_{m s}=\sqrt{\vartheta_{m a}^{2}+\vartheta_{m f}^{2}+\vartheta_{m h}^{2}}
$$

From [2]; $\vartheta_{m a}=0.05, \vartheta_{m f}=0.10$ and $\vartheta_{m h}=0.07$. When these values are substituted Eq. (A10):

$$
\vartheta_{m s}=\sqrt{\vartheta_{m a}^{2}+\vartheta_{m f}^{2}+\vartheta_{m h}^{2}}=\sqrt{0.05^{2}+0.1^{2}+0.07^{2}}=0.1319
$$

The effective variability of the design capacity model is:

$$
\vartheta_{M}=0.5 \sqrt{\vartheta_{m s}^{2}+\vartheta_{m H}^{2}}
$$

Now $\vartheta_{m H}=0.2291$ and $\vartheta_{m s}=0.135$, therefore:

$$
\begin{aligned}
& \vartheta_{M}=0.5 \sqrt{\vartheta_{m s}^{2}+\vartheta_{m H}^{2}}= \\
& =0.5 \sqrt{0.1319^{2}+0.2291^{2}}=0.1322
\end{aligned}
$$

\section{A2.0 PITTING STRENGTH VARIABILITY}

In section 4.2, the compressive yield strength is correlated with the tensile strength of linearly-symmetric (even) materials by the yield strength ratio $\left(\alpha_{y t}\right)$ and with linearly-asymmetric (un-even) materials by $\alpha_{y t}$ and compressive strength factor $\left(\alpha_{u c}\right)$. These parameters are not usually provided in commonly available mechanical property datasets. Different sources were researched to obtain data that could be analyzed to generate representative values for the parameters. Based on GCI data in IS 2009 [35], an average value of $\alpha_{y t}$ was found to be 0.563 and an average value of $\alpha_{u c}$ was found to be 3.386. The yield strength of gray cast iron is based on $0.01 \%$ strain offset. Values were higher than the average for low-strength GCI and lower for high-strength GCI. From available data of strengths for DCI in [1, 31], an average value of $\alpha_{y t}$ was found to be 0.736 , while that for CGI was 0.70 . The sample size is 5 . By analyzing ADI data in [20], an average value of $\alpha_{y t}$ was found to be 0.731 and an average value of $\alpha_{u c}$ was found to be 1.490 . The sample size is 5. A search of proper data of copper alloys in [36] yielded an average value of $\alpha_{y t}$ equal to 0.50 for cast bronze and 0.40 for cast brass. The sample size for bronzes is 20 and that for brass is 9. Wrought copper alloys can be heat treated, strained or worked hardened, as well as age-hardened. These treatments produce a range of mechanical properties that are difficult to characterize in simple term. Table A1 gives a summary of the above analysis.

There is ample evidence of the variability of mechanical properties of materials [2]. A practical way to characterize variability is to specify the mean value and coefficient of variation (cov) for the strength data. The $\operatorname{cov}$ is the ratio of standard deviation to the mean of a sample. The cov of tensile yield strength for wrought steel is about $7 \%$ and for structural steel, it is about $10 \%$ [2]. The cov for wrought copper alloys with respect to yield strength will be taken as $\vartheta_{y c}=0.10$. Cast metals have large numbers of voids in their lattices that can compromise strength in tension [37]. Dobrovolsky et al. [38, p. 45] assumed that undetected defects may reduce strength by $5-10 \%$ in forged parts, while they may reduce strength by $15-20 \%$ in cast parts. Hence cast products may exhibit up to about $10 \%$ reduction of strength compared to wrought products; or cov of about $3 \%$ to $4 \%$ increase in variability. For cast copper alloy and cast iron materials, it is assumed here that $\vartheta_{y c}=0.13$;

\begin{tabular}{|c|c|c|c|c|}
\hline Material & $\begin{array}{c}\text { Yield Strength } \\
\text { Ratio }\end{array}$ & $\begin{array}{c}\text { Compressive } \\
\text { Strength Factor }\end{array}$ & $\begin{array}{c}\text { Yield Strength Ratio } \\
\text { COV }(\%)\end{array}$ & $\begin{array}{c}\text { Compressive Strength } \\
\text { Factor COV }(\%)\end{array}$ \\
\hline Gray cast iron & 0.563 & 3.386 & \multirow{4}{*}{3} & 7 \\
\hline Austempered cast iron & 0.731 & 1.490 & & 7 \\
\hline Compacted graphite iron & 0.700 & \multirow{4}{*}{1.000} & & \multirow{4}{*}{2} \\
\hline Ductile iron & 0.736 & & & \\
\hline Cast brass & 0.400 & & 10 & \\
\hline Cast bronze & 0.500 & & 6 & \\
\hline
\end{tabular}
that is, about $3 \%$ increase in cov above wrought products. Poisson's ratio may be considered deterministic, but a cov of 0.02 [2] is suggested in critical designs. The approximations and estimation uncertainty in calculations is assumed to be associated 0.05. Table A2 summarizes the foregoing discussions.

Table A1: Yield Strength Ratios and Compressive Strength Factors for Cast Iron and Copper Alloy Materials 
According to Ullman [39], if the material properties are well known, use a cov of 0.05 and if the material properties are not well known, use a cov of 0.10 to 0.15 . Hence the cov assumed for cast products is within suggested range.

Table A2: Covs for Some Strength Parameters

\begin{tabular}{|l|c|}
\hline \multicolumn{1}{|c|}{ Strength Parameters } & COV \\
\hline Poisson's ratio & 0.02 \\
\hline Wrought material-yield/tensile strength & 0.10 \\
\hline Cast material-yield/tensile strength & 0.13 \\
\hline Miscellaneous & 0.05 \\
\hline
\end{tabular}

The variety of methods for modifying the mechanical strengths of copper alloys which include heat treatment, strain and age hardening and the multiplicity of alloy grades make it practically difficulty to correlate yield strength and tensile strength in a single factor. Therefore, using the yield strength to estimate the pitting strength appears more reasonable.

Equations (6), (13), and (15) provide functional relationships for estimating strength in terms of independent parameters. Eq. (6) may be summarized in symbolic form as in Eq. (A5a) and the cov is expressed in Eq. (A5b).

$$
S_{c}^{\prime}=f\left(v, S_{y c}\right) \quad \vartheta_{C}=\sqrt{\vartheta_{y c}^{2}+\vartheta_{v}^{2}+\vartheta_{m c}^{2}}
$$

When pitting strength is estimated from compressive yield strength for wrought products, then from Eq. (A14) above:

$$
\vartheta_{C}=\sqrt{0.10^{2}+0.02^{2}+0.05^{2}}=0.114
$$

When pitting strength is estimated from compressive yield strength, for cast products, then from Eq. (A14) above:

$$
\vartheta_{C}=\sqrt{0.13^{2}+0.02^{2}+0.05^{2}}=0.141
$$

When tensile strength data is available, then for even materials such as DCI, CGI and copper alloys; Eq. (13) is the functional strength relationship. It may be summarized in symbolic form as in Eq. (A6a) and the cov is expressed in Eq. (A6b).

$$
\begin{aligned}
& S_{c}^{\prime}=f\left(v, \alpha_{y t}, S_{u t}\right) \\
& \vartheta_{C}=\sqrt{\vartheta_{y t}^{2}+\vartheta_{v}^{2}+\vartheta_{u t}^{2}+\vartheta_{m c}^{2}}
\end{aligned}
$$

When tensile strength data is available for wrought even materials like copper alloys:

$$
\vartheta_{C}=\sqrt{0.03^{2}+0.02^{2}+0.10^{2}+0.05^{2}}=0.118
$$

Table A3: Evaluation of Nominal Design Factor at $99 \%$ Reliability
When tensile strength data is available, then for even cast iron materials like DCI and CGI:

$$
\vartheta_{C}=\sqrt{0.03^{2}+0.02^{2}+0.13^{2}+0.05^{2}}=0.144
$$

When tensile strength data is available, then for cast brass materials:

$$
\vartheta_{C}=\sqrt{0.10^{2}+0.02^{2}+0.13^{2}+0.05^{2}}=0.173
$$

When tensile strength data is available, then for cast bronze:

$$
\vartheta_{C}=\sqrt{0.06^{2}+0.02^{2}+0.13^{2}+0.05^{2}}=0.153
$$

When tensile strength data is available, then for uneven materials such as GCI, ADI; Eq. (15) is the functional strength relationship. It may be summarized in symbolic form as in Eq. (A7a) and the cov is expressed in Eq. (A7b).

$$
\begin{aligned}
& S_{c}^{\prime}=f\left(v, \alpha_{y t}, \alpha_{c}, S_{u t}\right) \\
& \vartheta_{C}=\sqrt{\vartheta_{y t}^{2}+\vartheta_{v}^{2}+\vartheta_{u c}^{2}+\vartheta_{u t}^{2}+\vartheta_{m c}^{2}}
\end{aligned}
$$

When tensile strength data is available, then for uneven materials such as gray cast iron and FA materials:

$$
\begin{aligned}
\vartheta_{C}= & \sqrt{0.03^{2}+0.02^{2}+0.07^{2}+0.13^{2}+0.05^{2}} \\
& =0.160
\end{aligned}
$$

\section{A3.0 NOMINAL DESIGN FACTOR}

In the lognormal reliability-based design factor model [40], the standard deviation of a design capacity model is expressed as:

$$
\begin{aligned}
& s_{m}=\sqrt{\ln \left[\left(1+\vartheta_{C}^{2}\right)\left(1+\vartheta_{M}^{2}\right)\right]} \\
& n_{o}=\exp \left[s_{m}\left(z+0.5 s_{m}\right)\right]
\end{aligned}
$$

\begin{tabular}{|c|c|c|c|c|c|c|c|}
\hline \multirow{3}{*}{ Parameter } & \multicolumn{2}{|c|}{ Yield Strength } & \multicolumn{5}{|c|}{ Tensile Strength } \\
\hline & \multirow[b]{2}{*}{ Wrought } & \multirow[b]{2}{*}{ Cast } & \multirow[b]{2}{*}{ Wrought } & \multicolumn{4}{|c|}{ Cast } \\
\hline & & & & Even-Cast Iron & $\begin{array}{l}\text { Uneven- } \\
\text { Cast Iron }\end{array}$ & Bronze & Brass \\
\hline Strength cov & 0.114 & 0.141 & 0.118 & 0.144 & 0.160 & 0.153 & 0.173 \\
\hline Model capacity cov & 0.132 & 0.132 & 0.132 & 0.132 & 0.132 & 0.132 & 0.132 \\
\hline Effective cov & 0.174 & 0.192 & 0.176 & 0.195 & 0.206 & 0.201 & 0.216 \\
\hline Nominal design factor & 1.522 & 1.592 & 1.529 & 1.604 & 1.650 & 1.629 & 1.692 \\
\hline
\end{tabular}

The probabilistic design factor, which is also called reliability factor, is obtained as [40]:

ASTM specifies minimum strength at a reliability of $99 \%$ and the corresponding unit normal variate is $z=$ 2.326. The nominal design factor is evaluated by combing Eq. (A8) and Eq. (A9), given the values of the parameters $\vartheta_{C}, \vartheta_{M}$ and $z$. Table A3 is a summary of the evaluation of the nominal design factor for cast iron and copper alloy materials at a reliability of $99 \%$. From the average values of the nominal design factor for wrought and cast products, cast products seem to have about $93.4 \%$ of the strength of wrought products. 


\section{ACKNOWLEDGEMENTS}

This study was supported with funds and facilities from the College of Science, Engineering, and Technology (COSET) Research Fund and the University Faculty Development Fund of Texas Southern University, Houston, Texas. The authors are very grateful for this support.

\section{NOMENCLATURE}

ADI

CGI

DCI

GCI

$\mathrm{COV}$

HVN

1,2

a

B

$b_{e}$

E

$E_{1}$

$E_{2}$

$E_{\mathrm{c}}$

$F_{\mathrm{c}}$

$k_{0}$

$k_{s}$

$k_{p}$

$k_{c}$

$K_{a}$

$K_{i}$

$K_{s}$

$n_{c}$

$n_{H}$

$n_{0}$

$r_{1}$

$r_{2}$

$s_{m}$

$S_{c}$

$S_{c}^{\prime}-$

$S_{c}^{*}-$

$S_{y c}$

$S_{y c}^{*}-$

$S_{u t}$

$z$

$Z_{c}$

$\alpha_{y t}$

$\rho$

$\sigma_{H}$

$\sigma_{e q}$

$v$

$v_{1}$

$v_{2}$

$\lambda_{e}$

$\vartheta_{E}^{\prime}-$

$\vartheta_{E}$

$\vartheta_{k s}$

$\vartheta_{E c}$

FME Transactions $\vartheta_{b} \quad \quad \operatorname{cov}$ of $b_{e}$

$\vartheta_{\rho} \quad \operatorname{cov}$ of $\rho$

$\vartheta_{m c} \quad$ miscellaneous cov for approximations

$\vartheta_{k a} \quad$ cov of $K_{a}$

$\vartheta_{k i} \quad$ cov of $K_{i}$

$\vartheta_{m s} \quad$ cov for general miscellaneous variability

$\vartheta_{m a} \quad$ cov for capacity model accuracy

$\vartheta_{y c} \quad$ cov for compressive or tensile yield strength

$\vartheta_{y c}^{*}-\quad$ cov contact yield strength

$\vartheta_{v} \quad \quad \quad \operatorname{cov}$ for Poisson's ratio

$\vartheta_{m f} \quad$ cov for failure model correlation with

mechanical capability

$\vartheta_{m h} \quad$ cov for human related variability

$\vartheta_{M} \quad$ effective cov for capacity model

$\vartheta_{C} \quad$ cov for strength or mechanical capability

\section{REFERENCES}

[1] Budynas, R. G. et al (2010), Shigley's Mechanical Engineering Design, 9th ed., McGraw Hill Education.

[2] Edward E. Osakue, Anetor, L., Harris, K., An Estimate of the Pitting Strength of Steel Materials, FME Transactions (2021) 49, 1 -120; doi:10.5937fme 21010010.

[3] Tu, S-T, Zhang, X-C, (2016), Fatigue Crack Initiation Mechanisms, Materials Science and Materials Engineering, Elsevier. Doi:10.1016/B9780-12-803581-8.02852-6.

[4] Šraml M., Flašker, J., (2007), Computational Approach To Contact Fatigue Damage Initiation Analysis Of Gear Teeth Flanks, Int J Adv Manuf Technol, (2007) 31:1066-1075; DOI 10.1007/s00170-0050296-2

[5] Polasik, S. J., Williams, J. J., and Chawla, N. (2001), Fatigue Crack Initiation and Propagation in Ferrous Powder Metallurgy Alloys, Advances in Powder Metallurgy and Particulate Materials, p. 2042-2056

[6] Stolarski, T. A., Chap. 3: Elements of Contact Mechanics, Tribology in Machine Design, Butterworth-Heinemann, Oxford, 2000

[7] Bhandari, V. B. Design of Machine Elements, 3rd ed., McGraw-Hill Education, New Delhi, P 142

[8] Dudley, D. W. (2009), Handbook of Practical Gear Design, CRC Press, Boca Raton.

[9] Ashby, M. F. Jones, D. R. H., (1986), Engineering Materials 2: An Introduction to Microstructures, Processing and Design, Pergamon Press, Oxford

[10] Mott, R. L. (2004), Machine Elements in Mechanical Design, 4th ed. (SI Units), Pearson Prentice hall, New York.

[11]Dennis P. Townsend, Common Problems and Pitfalls in Gear Design, NASA Technical Memorandum 88858, 1986; https://ntrs.nasa.gov/archive/nasa/casi .ntrs.nasa.gov/19870007600.pdf

[12]Zahavi, E. (1992), The Finite Element Method in Machine Design, Prentice Hall, Englewood Cliffs, New Jersey.

[13]Norton, R. L. (2000), Machine Design: An Integrated Approach, Prentice-Hall, Upper Saddle River, New Jersey, Chap. 7. 
[14] ASM Handbook, Volume 19: Fatigue and Fracture, ASM International, 1996

[15] Collins, J. A. et al (2010), Mechanical Design of Machine Elements and Machines: A Failure Prevention Perspective, 2nd ed., John Wiley and Sons, New York, p. 864

[16] Osakue, E. E., (1999), A Study of Friction During Low-Velocity Impact, Ph.D. Thesis, Department of Mechanical Engineering, University of New Brunswick, Fredericton, Canada.

[17] Kalpankjian, S., Schmid, R. S. (2018), Manufacturing Processes for Engineering Materials, 6th ed. (SI ed.), Pearson (India),

[18]Engineering Toolbox, Poisson's Ratio; https://www .engineeringtoolbox.com/poissons-ratio-d_1224.html

[19]Material Classification; http://www.lucla.asia/2 /upload/material_classification.pdf

[20]Austempered Ductile Iron; https://www.applied process.com/wp-content/uploads/2018/09/2017-0330-Typical-Properties-of-FA-in-lb-Version.pdf

[21] Shigley, J. E., Mischke, C. R., Standard Handbook of Machine Design, 2nd Edition, 1996.

[22] Review of Plane Stress and Plane Strain Elasticity http://w3.uacg.bg/UACEG_site/acadstaff/userfiles/st udy_bg_162_L_02_Plane_Elsticity.pdf

[23]Hess, P. E. et al (2002), Uncertainties in Material Strength, Geometric, and Load Variables, http://www.assak kaf .com /papers/Journals

[24] Cast Iron - eFatigue; https://www.efatigue.com /castiron

[25] Noguchi, T, and Nagaoka, K., On the Notch Strength of Cast Iron - HUSCAP; Jan 31, 1983; https://eprints.lib.hokudai.ac.jp/dspace/bitstream/211 5/41771/1/112_35-46.pdf

[26] Mohammed, A. D., Kachit, M. Effects of Features of Graphite Nodules on Stress Concentration in Nodular Graphite Cast Iron Material under MultiAxial LoFAng, International Journal of Applied Engineering Research 12(5):656-663.

[27]Austempered Ductile Iron; https://www.ductile.org /didata/Section4/4intro.htm

[28] Kharagpur , Module 3, Design for Strength, Version 2 ME, IIT PTEL; https://docplayer.net/11615428Module-3-design-for-strength-version-2-me-iitkharagpur.html

[29] Hearn, E. J, Stress Concentration - an overview, In Mechanics of Materials 1 (Third Edition), 1997

[30] Common Material Properties; https://www.efunda .com/materials/common_matl/

[31] Schmid, S. R. et al. Fundamentals of Machine Elements, 3rd ed. CRC Press, New York.

[32] ANSI/AGMA 2001-D04, Fundamental Rating Factors and Calculation Methods for Involute Spur and Helical Gear Teeth; http://wp.kntu.ac.ir/asgari/ AGMA\%202001-D04.pdf

[33] Introduction and Perspectives, Carburizing: Microstructures and Properties, ASM International, 1999; www.asminternational.org
[34]Petrov, M., Chernilevsky, D., Berezovsky, Y. (1988), Machine Design, MIR, Moscow.

[35]IS 2009 Indian Standard; Grey Iron Castings Specification (Fifth Revision); http://www.iitk.ac .in/ce/test/IS-codes/is.210.2009.pdf

[36]Copper Alloys - Copper Development Association Inc.; www.copper.org

[37] Ashby, M. F., Jones, D. R. H., (2012), Engineering Materials 1: An Introduction to Properties, Applications and Design, 4th ed. Elsevier, New York, p. 127.

[38] Dobrovolsky, V., Zablonsky, K., Mak, S., Radchik, A., and Erlikh, L. (1965), Machine Elements, Foreign Language Pub. House, Moscow.

[39] Ullman, G. D, Appendix C: The Statistical Factor of Safety, The Mechanical Design Process, 2nd ed., McGraw-Hill, New York, 2009.

[40] Osakue, E. E. and Anetor, L, A Method for Estimating a Probabilistic Design Factor, Int'1 Journal of Research in Engineering and Technology, Vol. 06, Issue 08, pp. 119 - 129, 2017.

\section{ПРОРАЧУН ЈАЧИНЕ ПИТИНГА КОД МАТЕРИЈАЛА ОД ЛИВЕНОГ ГВОЖЪА И ЛЕГУРА БАКРА}

\section{Е.Е.Осакуе, Л.Анетор, К.Харис}

У раду је приказан покушај предвиђања јачине питинга код материјала од ливеног гвожђа и легура бакра у погледу чврстоће приноса и чврстоће на притисак за поузданост од $99 \%$ са $10^{7}$ циклуса оптерећења. Фактор пропорционалности повезује чврстоћу приноса и чврстоћу на притисак са затезном чврстоћом материјала од нодуларног челика и легуре бакра. Два фактора пропорционалности су коришћена за материјале од кртог ливеног гвожђа. Формулација јачине питинга обједињује номинални фактор дизајна са 96\% поузданости који се израчунава на основу модела вероватноће базираног на логфункцији густине вероватноће.

Прорачун јачине питинга заснован на предвиђањима упоређен је са прорачунима АГМА удружења и подацима из других извора. Предвиђене вредности за сиви лив кретале су се од -11,28\% до 25\%. Вредности за нодуларни лив су одступале од АГМА вредности за $-30,28 \%$ до $1,73 \%$ а за нодуларни лив од $16,76 \%$ до $36,34 \%$. Код ливене бронзе варирање је било у распону од 11,17\% до 14,73\% али је величина узорка била мала. Варијације код свих врста материјала се могу приписати бројним факторима који утичу на отпорност на питинг. Пошто (јавно) нису доступни подаци о јачини питинга код многих разреда ливеног гвожђа и легура бакра, они се могу израчунати на основу израза развијеног у овом раду. Јачина питинга се код наведених материјала може израчунати и код почетних одмеравања дизајна, чиме би се избегло дуготрајно и скупо испитивање замора услед контакта у почетним фазама дизајнирања, што је свакако од значаја за валидацију дизајна. 